\title{
ISOLASI BAKTERI PENGIKAT NITROGEN DENGAN MENGGUNAKAN MEDIA JENSEN
}

\author{
Feizia Huslina ${ }^{1 *}$ Diannita Harahap ${ }^{2}$ \\ 1 Prodi Biologi/Universitas Islam Negeri Ar-Raniry Banda Aceh, feiziahuslina@gmail.com \\ 2 Prodi Biologi/Universitas Islam Negeri Ar-Raniry Banda Aceh, diannitaharahap@yahoo.com
}

\begin{tabular}{l} 
INFO ARTIKEL \\
\hline RiwayatArtikel: \\
Diterima: 01-07-2019 \\
Disetujui: 11-08-2019
\end{tabular}

\section{Kata Kunci:}

Bakteri pengikat nitrogen

media Jensen

isolasi

\begin{abstract}
ABSTRAK
Abstrak: Bakteri pengikat nitrogen adalah jenis bakteri yang paling banyak ditemukan di tanah dan sebagiannya bersimbiosis dengan akar tumbuhan. Bakteri ini mengikat nitrogen di udara dan mengubahnya menjadi nitrat yang kemudian digunakan oleh tumbuhan. Media Jensen adalah media selektif yang umumnya digunakan untuk menumbuhkan bakteri pengikat nitrogen. Penelitian ini bertujuan untuk mengisolasi bakteri pengikat nitrogen dengan menggunakan media Jensen. Bakteri diisolasi dari rizosfer di sekitar UIN Ar-Raniry, Banda Aceh dan dilakukan karakteristik morfologi dan Optical Density (OD). Empat isolat (ISA, IS-B, IS-C, IS-D) ditemukan pada serial pengenceran $10^{-2}$ dan $10^{-4}$ dan isolat $D$ (IS-D) memiliki nilai Optical Density (OD) tertinggi yaitu sebesar 0,373.

Abstract: Nitrogen-fixing bacteria is mostly found in soil, and some of the bacteria are related to plant root. This bacteria fix atmospheric nitrogen and change it to nitrate, which utilized by plants. Jensen's medium is a selective medium which can grow nitrogen-fixing bacteria. This research aimed to isolate nitrogen-fixing bacteria by using Jensen's medium. The bacteria were isolated from rhizosphere around UIN Ar-raniry, Banda Aceh. Morphological characteristics and Optical Density (OD) were observed. Four isolates (IS-A, IS-B, IS-C, IS-D) were found from dilution of $10^{-2}$ dan $10^{-4}$ and isolate $D(I S-D)$ had the highest Optical Density (OD) which about 0,373.
\end{abstract}

\section{A. LATAR BELAKANG}

Bakteri pengikat nitrogen adalah bakteri yang banyak ditemukan di tanah, dan sebagiannya bersimbiosis dengan akar tumbuhan. Bakteri ini mengikat nitrogen di udara dan mengubahnya menjadi nitrat yang kemudian digunakan oleh tumbuhan. Mikroba yang mampu untuk mengikat nitrogen disebut dengan diazotrop. Hingga saat ini, diazotrop diidentifikasi ke dalam 13 filum, yaitu: Actinobacteria, Chlorobi, Chloroflexi, Cyanobacteria, Firmicutes. Proteobacteria, Aqulficae, Chryslogenetes, Deferribacteres, Fusobacteria, Nitrospirae, Spirochaetes, dan Verrucomicrobiain [1,2]. Sebagian besar bakteri pengikat nitrogen bersifat heterotrofik seperti pada golongan spesies Azotobacteria dan Azospirillum. Namun ada juga yang bersifat autotrofik, seperti Rhodospirillacae. Bakteri pengikat nitrogen yang bersifat autotrofik menggunakan energi cahaya dalam melakukan proses penambatan nitrogen. Beberapa bakteri dapat melakukan proses pengikatan nitrogen secara anaerob [3].
Penelitian tentang bakteri penambat nitrogen telah banyak dilakukan dan diterapkan dalam berbagai bidang, di antaranya bidang pertanian, lingkungan, dan industri Beberapa penelitian menunjukkan kajian tentang kelompok bakteri pengikat nitrogen seperti Rhizobium dan Frankia yang terdapat pada bintil akar tumbuhan berpembuluh. Menurut [1], Rhizobium dapat ditemukan pada tumbuhan jenis kacang-kacangan terutama pada family Fabaceae, sedangkan Frankia dapat ditemukan pada delapan famili tumbuhan. Bakteri pengikat nitrogen dari kelompok Azoarcus, Achromobacter, Burkholderia, Gluconoacetobacter, Herbaspirillum, Klebsiella, dan Serratia diketahui memiliki kemampuan sebagai biofertilizer untuk tumbuhan pangan $[1,2]$. Bakteri pengikat nitrogen juga memiliki kemampuan lain, yaitu meremediasi senyawa merkuri.

Bakteri ini dapat tumbuh pada media nitrogen-free. Media Jensen adalah salah satu media selektif yang dapat digunakan untuk menumbuhkan bakteri pengikat nitrogen. Tujuan penelitian ini adalah mengisolasi bakteri pengikat nitrogen dengan menggunakan media selektif Jensen. Isolasi dilakukan dari rhizosfer pada 
sekitar wilayah UIN Ar-Raniry, Banda Aceh.

\section{B. METODE PENELITIAN}

\section{Pengambilan Sampel}

Sampel diambil di Universitas Islam Negeri (UIN) Ar-Raniry, Banda Aceh. Sebanyak 20 g tanah di sekitar perakaran tanaman dengan kedalaman 20 cm diambil dan dimasukkan ke dalam kantong plastik dan dibawa ke laboratorium.

\section{Isolasi Bakteri Pengikat Nitrogen}

Sebanyak $10 \mathrm{~g}$ sampel dimasukkan ke dalam 90 $\mathrm{ml}$ larutan $\mathrm{NaCl}$ fisiologis (pengenceran $10^{-1}$ ), kemudian dihomogenkan dengan menggunakan vortex. Sebanyak $1 \mathrm{ml}$ dari larutan tersebut dimasukkan ke dalam $9 \mathrm{ml}$ larutan $\mathrm{NaCl}$ fisiologis $\left(10^{-2}\right)$, dan dilakukan seterusnya hingga pengenceran $10^{-6}$. Sebanyak $1 \mathrm{ml}$ larutan dari setiap pengenceran tersebut dituang ke dalam media Jensen, dan diinkubasi pada suhu $37^{\circ} \mathrm{C}$ selama 48 jam [4]. Bakteri yang tumbuh kemudian dikulturkan kembali hingga kultur murni dapat diperoleh.

\section{Pengamatan karakteristik morfologi}

Isolat murni yang ditemukan kemudian diamati bentuk koloni bakteri, bentuk bagian tepian koloni, dan warna koloni bakteri, dan elevasi koloni.

\section{Perhitungan Optical Density (OD)}

Sebanyak $1 \mathrm{ml}$ suspense isolat bakteri dimasukkan kedalam kuvet. Aquades dijadikan sebagai blanko. Suspensi tersebut kemudian diukur nilai absorbansi menggunakan spektrofotometer dengan panjang gelombang $60 \mathrm{~nm}$.

\section{HASIL DAN PEMBAHASAN}

\section{Isolasi Bakteri Pengikat Nitrogen}

Berdasarkan hasil penelitian, bakteri pengikat nitrogen yang diperoleh berjumlah empat isolat (IS-1, IS-2, IS-3, dan IS-4) pada serial pengenceran $10^{4}$ dan $10^{-2}$. Pengamatan morfologi keempat isolat tersebut dilakukan berdasarkan warna koloni, bentuk koloni, tepian koloni, dan permukaan koloni

Tabel 1.

Morfologi isolat bakteri pengikat nitrogen

\begin{tabular}{ccccc}
\hline KODE ISOLAT & Bentuk Koloni & Bentuk Tepian Koloni & Warna Koloni & Elevasi Koloni \\
\hline IS-A (10-4) & Circular & Rata & Putih Susu & Flat \\
IS-B (10-2) & Circular & Bergerigi & Putih Kekuningan & Flat \\
IS-C (10-2) & Circular & Rata & Putih Susu & Raised \\
IS-D (10-2) & Circular & Rata & Putih Susu & Raised \\
\hline & & suhu yang & sesuai dan nutrisi yang memadai
\end{tabular}

Berdasarkan Tabel 1 di atas, dapat dilihat bahwa keempat isolat memiliki bentuk koloni yang sama yaitu circular. Bentuk tepian koloni (rata), dan warna koloni(putih susu) yang sama hanya dimiliki oleh tiga isolat, yaitu IS-A, IS-C, dan IS-D, sedangkan isolat IS-B memiliki warna koloni putih kekuningan dan bentuk tepian koloni yang bergerigi. Isolat IS-A dan IS-B memiliki elevasi koloni yang sama (flat), sedangkan isolat IS-C dan IS-D memiliki elevasi koloni raised.

Tabel 2.

Rata-rata Optical Density (OD) isolat bakteri pengikat nitrogen

\begin{tabular}{cc}
\hline KODE ISOLAT & OD \\
\hline IS-A & 0.203 \\
IS-B & 0.170 \\
IS-C & 0.247 \\
IS-D & 0.373 \\
\hline
\end{tabular}

Berdasarkan tabel di atas, dapat dilihat bahwa isolat D (IS-D) memiliki nilai Optical Density (OD) yang tinggi dibandingkan dengan isolat C (IS-C), isolat A (ISA) dan isolat $B$ (IS-B). Nilai OD yang tinggi menunjukkan bahwa isolat tersebut memiliki tingkat pertumbuhan yang tinggi. Adanya $\mathrm{pH}$ yang optimum, menyebabkan densitas bakteri menjadi tinggi. Suhu

merupakan salah satu faktor yang penting dalam pertumbuhan bakteri. Terdapat beberapa jenis bakteri yang dapat hidup pada kisaran suhu yang luas, dan ada juga bakteri jenis lainnya yang hanya dapat hidup pada rentang suhu yang terbatas. Pada umumnya kisaran suhu pertumbuhan mikroba terletak antara $0^{\circ} \mathrm{C}-90^{\circ} \mathrm{C}$ [5]. Faktor lain yang mempengaruhi pertumbuhan bakteri adalah salinitas. Beberapa penelitian menunjukkan bahwa bakteri pengikat nitrogen gram negatif dapat tumbuh pada tingkat salinitas yang rendah maupun tinggi $[6,7]$.

Media selektif yang digunakan pada penelitian ini adalah media Jensen. Berdasarkan hasil penelusuran pada beberapa jurnal, media yang paling efektif yang dapat digunakan untuk mengisolasi bakteri pengikat nitrogen adalah media Jensen. Media ini mengandung nutrisi yang dibutuhkan oleh bakteri pengikat nitrogen yaitu sukrosa, dipotassium fosfat, magnesium sulfat, sodium klorida, ferrous sulfat, sodium molibdat, dan kalsium karbonat. Media Jensen diformulasikan menurut Jensen dan direkomendasikan untuk 
mendeteksi dan menumbuhkan bakteri pengikat nitrogen [8]. Pada media Jensen, sukrosa berfungsi sebagai sumber energi, sedangkan sodium molibdat dapat meningkatkan aktivitas pengikatan nitrogen [9]. Sodium klorida berfungsi untuk mempertahankan keseimbangan tekanan osmotik media. Kalsium dapat menstimulasi pembentukan nodul ketika mucul dalam bentuk klorida atau sulfat.

Bakteri pengikat nitrogen adalah bakteri yang bebas hidup di alam yang dapat tumbuh baik pada media yang tidak mengandung nitrogen. Bakteri ini memanfaatkan gas nitrogen atmosfer untuk proses sintesis protein sel. Protein sel tersebut kemudian dimineralisasi di dalam tanah yang kemudian menyebabkan adanya ketersediaan nitrogen bagi tanaman [10]. Bakteri ini juga hanya bersimbiosis dengan tanaman leguminosa dengan cara menginfeksi akar tanaman dan membentuk nodule. Sebagian besar bakteri pengikat nitrogen bersifat heterotrof yang membutuhkan jumlah karbon yang sedikit, seperti jenis Azotobacteria dan Azospirillum. Sebagian lainnya merupakan golongan autotrof, yang dapat mengurangi karbondioksida [11]. Pada umumnya, proses fiksasi atau pengikatan nitrogen hanya dapat terjadi secara anaerob, dan hanya beberapa strain dari jenis tertentu yang dapat menunjukkan proses tersebut [3].

Pada tahap isolasi, waktu yang digunakan untuk inkubasi adalah 48 jam. Pada waktu tersebut, pertumbuhan bakteri ini masih terbilang sedikit. Hal ini dapat dilihat pada pertumbuhan koloni yang muncul pada media selektif, dan tingkat kekeruhan bakteri ketika dikulturkan pada media cair (nutrient broth). Waktu inkubasi yang tidak lama menyebabkan pertumbuhan bakteri yang tidak terlalu banyak. Beberapa penelitian lain menggunakan waktu yang relatif lebih lama untuk menumbuhkan bakteri pengikat nitrogen yaitu selama tujuh hari $[12,13]$.

\section{SIMPULAN DAN SARAN}

Berdasarkan hasil penelitian, diperoleh empat jenis isolat (IS-A, IS-B, IS-C, IS-D) pada serial pengenceran $10^{-2}$ dan $10^{-4}$. Seluruh isolat memiliki bentuk koloni yang sama (circular) dan memiliki bentuk tepian, permukaan, dan warna koloni yang hamper sama. Isolat yang memiliki Optical Density (OD) tertinggi adalah isolat D (IS-D) dengan nilai 0,373 .

\section{UCAPAN TERIMA KASIH}

Penulis mengucapkan terima kasih kepada seluruh pihak yang telah membantu terutama pihak Pusat Penelitian UIN Ar-Raniry Banda Aceh dan mahasiswa yang terlibat aktif dalam menyelesaikan penelitian ini.

\section{DAFTAR RUJUKAN}

[1] Franche, C., Lindstrom, K., Elmerich, C. (2009). Nitrogen-fixing bacteria associated with leguminous and non-leguminous plants. Plant Soil, 321, 35-59.
[2] Dos Santos, P.C., Fang, Z., Mason, S.W., Setubal, J.C., Dixon, R. (2012). Distribution of nitrogen fixation and nitrogenase-like sequences amongst microbial genomes. BMC Genomics, 13, 162.

[3] Scow, J. K. (2007). Conversion of Gaseous Nitrogen. American Journal of Nitrogenous compounds, 29, 705788.

[4] Ponmurugan, K, Sankaranarayanan, A, Al-Dharbi, NA. (2012). Biological activities of plant growth promoting Azotobacter sp. isolat from vegetable crops rhizosphere soil. Journal of Pure and Applied Microbiology, 6, 1-10.

[5] Waluyo, L. (2005). Mikrobiologi Lingkungan. Malang: UMM Press.

[6] Quesada, E., Ventosa, A., Rodriguez-Valera, F., RamosCormenzana, A. (1982). Types and properties of some bacteria isolated from hypersaline soils. J. Appl. Bacteriol., 53, 155-161.

[7] Del Moral, A., Quesada, E., Ramos-Cormenzana, A., (1987). Distribution and types of bacteria isolated from an inland saltern. Ann. Inst. Pasteur Microbiol., 138, 59-66.

[8] Jensen, H. L. (1942). Pro Line Soc. N.S.W., 57,205-212.

[9] Ranganayaki, S., Mohan C., Ally Z. (1981). Effect of sodium molybdate on microbial fixation of nitrogen. Microbiology, 21, 607-10.

[10] Subba, Rao N. S. (1977). In: Soil Microorganisms and Plant Growth, Oxford and IBH Publishing Co., New Delhi, pp. 254-255.

[11] Graham, P. H. (2000). Nodule Formation in Legumes in Encydopedia of Microbiology. Academic Press, San Diego, pp. 59-65.

[12] Stella, M., Suhaimi, M. (2010). Selection of suitable growth medium for free-living diazotrophs isolated from compost. J. Trop. Agric. and Fd. Sc., 38, 211-219.

[13] Jiménez, D.J., Montana, J.S., Martinez, M.M. (2011). Characterization of Free Nitrogen Fixing Bacteria of The Genus Azotobacter in Organic Vegetable-Grown Colombian Soils. Brazilian Journal of Microbiology, 42: 846-858. 